\title{
FAKTOR-FAKTOR YANG MEMPENGARUHI PENGUNGKAPAN CORPORATE SOCIAL RESPONSIBILITY
}

\author{
Oleh : \\ Indira Shinta Dewi \\ Dan \\ Dita Nur Khafi \\ Fakultas Ekonomi Program Studi Akuntansi \\ Universitas Satya Negara Indonesia
}

\begin{abstract}
ABSTRAK
CSR merupakan bentuk komitmen suatu perusahaan terhadap lingkungan sosialnya atas kegiatan usaha yang mereka jalankan dan bersifat berkelanjutan . Beberapa faktor yang sering dihubungkan dalam pengungkapan CSR suatu perusahaan di antaranya adalah profitabilitas, leverage, ukuran perusahaan. Beberapa penelitian terdahulu memberikan hasil penelitian yang berbeda terhadap factor yang mempengaruhi pengungkapan corporate social responsibility

Tujuan penelitian ini adalah untuk mengetahui pengaruh profitabilas,leverage dan ukuran perusahaan terhadap pengungkapan CSR perusahaan pada perusahaan pertambangan yang terdaftar di Bursa Efek Indonesia periode 2013-2015. Sampel penelitian ini menggunakan teknik purposive sampling. Berdasarkan kriteria diperoleh sampel observasi sebanyak 59 perusahaan. Data yang digunakan adalah data sekunder yang bersumber dari laporan keuangan perusahaan. Menggunakan analis regresi linier berganda untuk menganalisis data. Hasil uji parsial menunjukkan bahwa profitabilitas tidak berpengaruh terhadap pengungkapan corporate social responsibility. Leverage tidak berpengaruh terhadap pengungkapan corporate social responsibility. Ukuran perusahaan berpengaruh terhadap pengungkapan corporate social responsibility
\end{abstract}

Kata kunci: profitabilitas, Leverage, Ukuran perusahaan, Corporate Social Responsibility

\section{PENDAHULUAN}

CSR merupakan bentuk komitmen suatu perusahaan terhadap lingkungan sosialnya atas kegiatan usaha yang mereka jalankan dan bersifat berkelanjutan. Contoh pelaksanaan CSR, yaitu melakukan kegiatan yang dapat memperbaiki kualitas lingkungan, bantuan infrastruktur dan beasiswa, pemberian dana untuk pemeliharaan sarana dan prasarana, sumbangan yang bersifat sosial untuk desa dan masyarakat banyak, khususnya masyarakat yang tinggal di sekitar perusahaan.

Pelaksanaan CSR sudah mulai dijalankan di Indonesia setelah disahkannya UndangUndang No.40 Tahun 2007 Pasal 74 Tentang Perseroan Terbatas yang menekankan bahwa setiap perseroan yang menjalankan kegiatan usahanya di bidang dan/ atau berkaitan dengan segala sumber daya alam wajib melaksanakan tanggung jawab sosial dan lingkungan. 
Kemudian hal tersebut dipertegas lagi dalam Peraturan Pemerintah No.47 Tahun 2012 tentang Tanggung Jawab Sosial dan Lingkungan Perseroan Terbatas yang menyatakan bahwa apabila terdapat perusahaan yang tidak melaksanakan tanggung jawab sosial dan lingkungan akan dikenai sanksi sesuai dengan ketentuan peraturan perundang-undangan.

Perusahaan yang melakukan pelaksanaan tanggung jawab sosial perlu diungkapkan dan dipertanggungjawabkan dalam laporan keuangan tahunan agar partisipasi perusahaan tersebut dapat diketahui oleh berbagai pihak yang berkepentingan. Selain itu juga untuk mematuhi aturan pemerintah yang berlaku.

Menilai pengungkapan CSR di Indonesia dapat menggunakan standar yang dikembangkan dari Global Reporting Initiative (GRI). Standar GRI dipilih karena telah diterima oleh umum dalam melaporkan kinerja ekonomi, lingkungan dan sosial dari suatu organisasi. Selain itu, standar GRI juga telah disetujui oleh berbagai pemangku kepentingan (www.globalreporting.org).

Banyak faktor yang sering dihubungkan dalam pengungkapan CSR suatu perusahaan. Di antaranya adalah profitabilitas, leverage, ukuran perusahaan, tipe perusahaan, kepemilikan saham publik maupun kepemilikan asing.

Menurut Hadi dan Sabeni dalam Karina (2013) menyatakan bahwa salah satu faktor yang mempengaruhi luas pengungkapan laporan tahunan suatu perusahaan adalah basis perusahaan tersebut. Basis perusahaan dapat dilihat dari kepemilikan sahamnya, apakah perusahaan tersebut mayoritas sahamnya dimiliki pemerintah atau dimiliki swasta/asing. Kondisi perusahaan sedikit banyak juga mempengaruhi kinerja serta luas penyajian laporan tahunan termasuk laporan sukarela perusahaan. Kondisi perusahaan dapat dilihat dari tipe perusahaan, ukuran perusahaan, leverage dan profitabiltas perusahaan (Puspitasari dalam Karina, 2013).

Salah satu dari faktor-faktor yang mempengaruhi pengungkapan CSR tersebut adalah profitabilitas. Profitabilitas merupakan gambaran atas kinerja operasi perusahaan. Baik buruknya kinerja perusahaan dapat dilihat dari tingkat profitabilitasnya. Saat tingkat profitabilitas perusahaan tinggi, maka perusahaan tersebut akan mengungkapkan tanggung jawab sosialnya lebih luas.

Faktor berikutnya yang sering diduga mempengaruhi pengungkapan CSR adalah leverage, yaitu tingkat ketergantungan perusahaan terhadap utang dalam membiayai kegiatan operasionalnya (Sembiring, 2005). Rasio leverage digunakan untuk mengukur sejauh mana aktiva yang dimiliki perusahaan dalam kemampuannya membiayai utang. Perusahaan dengan tingkat leverage yang tinggi akan melakukan pengungkapan tanggung jawab sosial seluasluasnya, hal itu dikarenakan sebagai bentuk informasi untuk para kreditor atas kinerja perusahaan dalam berkontribusi terhadap aturan pemerintah.

Ukuran perusahaan juga merupakan suatu faktor yang sering dihubungkan mempengaruhi pengungkapan CSR. Ukuran perusahaan adalah suatu skala dimana dapat diklasifikasikan besar kecilnya perusahaan. Keseluruhan aktiva yang dimiliki perusahaan dapat digunakan untuk menggambarkan seberapa besar kemampuan perusahaan dalam mendanai kegiatan operasionalnya. Perusahaan yang besar cenderung memiliki aktivitas yang lebih banyak dan kompleks, maka pelaksanaan CSR yang dilakukan oleh perusahaan dapat digunakan untuk menghindari resiko yang akan ditanggung di masa depan. 
Beberapa penelitian mengenai faktor-faktor yang mempengaruhi pengungkapan CSR telah dilakukan sebelumnya. Seperti penelitian yang dilakukan oleh Nur dan Priantinah (2012) dengan enam variabel, yaitu profitabilitas, ukuran perusahaan, kepemilikan saham publik, dewan komisaris, leverage dan pengungkapan media. Hasil penelitian menunjukkan bahwa profitabilitas tidak berpengaruh terhadap pengungkapan CSR. Sedangkan, ukuran perusahaan berpengaruh positif dan signifikan terhadap pengungkapan CSR, serta leverage berpengaruh negatif dan signifikan terhadap pengungkapan CSR.

Penelitian lain yang dilakukan oleh Yuliawati dan Sukirman (2015) dengan empat variabel, yaitu kepemilikan asing, ukuran perusahaan, profitabilitas, dan leverage. Hasil penelitian menunjukkan bahwa ukuran perusahaan dan profitabilitas berpengaruh signifikan positif terhadap pengungkapan CSR. Sedangkan, leverage berpengaruh signifikan negatif terhadap pengungkapan CSR.

Adapun objek penelitian yang digunakan adalah perusahaan pertambangan yang terdaftar di Bursa Efek Indonesia periode tahun 2013-2015. Pelaksanaan CSR pada perusahaan pertambangan telah diatur dalam Undang-Undang No.22 Tahun 2001, serta perusahaan pertambangan dipilih karena kegiatan utama operasionalnya adalah mengeksploitasi sumber daya alam yang tersedia dan besar kemungkinan akan merusak lingkungan alam dan sosial apabila tidak adanya bentuk kepedulian dari perusahaan tersebut.

Berikut contoh kasus pelanggaran tanggung jawab sosial perusahaan yang dilakukan oleh perusahaan pertambangan terjadi pada Desember 2014 lalu, dimana Greenpeace mengeluarkan laporan yang mengungkapkan bahwa perusahaan pertambangan batubara telah meracuni air di Kalimantan Selatan. Laporan tersebut menyajikan bukti yang kuat bahwa perusahaan-perusahaan batubara itu telah membuang limbah berbahaya ke dalam sungai dan sumber-sumber air masyarakat. Hal ini jelas melanggar standar nasional untuk pembuangan limbah di pertambangan (www.greenpeace.org).

Dari uraian di atas membuat penulis tertarik ingin melakukan penelitian mengenai faktor-faktor yang mempengaruhi pengungkapan corporate social responsibility dengan menggunakan variabel profitabilitas, leverage dan ukuran perusahaan. Maka penulis akan melakukan penelitian dengan judul "FAKTOR-FAKTOR YANG MEMPENGARUHI PENGUNGKAPAN CORPORATE SOCIAL RESPONSIBILITY”.

\section{Perumusan Masalah}

1. Apakah profitabilitas berpengaruh terhadap pengungkapan corporate social responsibility ?

2. Apakah leverage berpengaruh terhadap pengungkapan corporate social responsibility?

3. Apakah ukuran perusahaan berpengaruh terhadap pengungkapan corporate social responsibility?

\section{Tujuan Penelitian}

a. Untuk mengetahui apakah profitabilitas berpengaruh terhadap pengungkapan corporate social responsibility.

b. Untuk mengetahui apakah leverage berpengaruh terhadap pengungkapan corporate social responsibility.

c. Untuk mengetahui apakah ukuran perusahaan berpengaruh terhadap pengungkapan corporate social responsibility. 


\section{TINJAUAN PUSTAKA}

\section{Teori Stakeholder}

Nor Hadi dalam bukunya Corporate Social Responsibility (2011:93) mendefinisikan stakeholder adalah "semua pihak baik internal maupun eksternal yang memiliki hubungan baik bersifat mempengaruhi maupun dipengaruhi, bersifat langsung maupun tidak langsung oleh perusahaan."

Dengan demikian yang dimaksud stakeholder yaitu: pemerintah, perusahaan pesaing, masyarakat sekitar, lembaga di luar perusahaan (LSM dan sejenisnya), lembaga pemerhati lingkungan, para karyawan, dan lain sebagainya yang keberadaannya sangat mempengaruhi dan dipengaruhi oleh perusahaan.

Menurut Ghozali dan Chariri (dalam Aprilia, 2016), "teori stakeholder menyatakan bahwa perusahaan bukanlah entitas yang hanya beroperasi untuk kepentingannya sendiri, tetapi juga harus memperhatikan kepentingan stakeholder." Karena mereka adalah pihak yang mempengaruhi dan dipengaruhi baik secara langsung maupun tidak langsung atas aktivitas serta kebijakan yang diambil dan dilakukan oleh perusahaan. Jika hal ini tidak dilakukan, maka perusahaan akan menuai protes.

Dengan demikian, perusahaan hendaknya menjaga reputasinya yaitu dengan menggeser pola orientasi (tujuan) yang semula semata-mata diukur dengan economic measurement yang cenderung shareholder orientation, ke arah memperhitungkan faktor sosial sebagai wujud kepedulian dan keberpihakan terhadap masalah sosial kemasyarakatan (stakeholder orientation) (Nor Hadi, 2011:95).

Perusahaan tidak hanya sekedar bertanggung jawab terhadap para pemilik (shareholder) sebagaimana terjadi selama ini, namun bergeser menjadi lebih luas yaitu sampai ranah sosial kemasyarakatan (stakeholder), selanjutnya disebut tanggung jawab sosial (social responsibility). "Fenomena ini terjadi karena adanya tuntutan dari masyarakat akibat negative externalities yang timbul serta ketimpangan sosial yang terjadi" (Harahap dalam Efendi, 2015).

Salah satu strategi untuk menjaga hubungan dengan para stakeholder perusahaan adalah dengan melaksanakan CSR. Dengan pelaksanaan CSR diharapkan keinginan dari stakeholder dapat terakomodasi sehingga akan menghasilkan hubungan yang harmonis antara perusahaan dengan stakeholdernya. Hubungan yang harmonis akan berakibat pada perusahaan dapat mencapai keberlanjutan atau kelestarian perusahaannya (sustainability) (Fahrizqi, 2010).

\section{Pengungkapan Corporate Social Responsibility}

The World Business Council for Sustainable Development (WBCSD) (dalam Gultom, 2013) mendefinisikan CSR sebagai berikut :

Corporate Social Responsibility (CSR) sebagai komitmen bisnis untuk memberikan kontribusi bagi pembangunan ekonomi berkelanjutan, melalui kerja sama dengan para karyawan serta perwakilan mereka, keluarga mereka, komunitas setempat maupun masyarakat umum untuk meningkatkan kualitas 
kehidupan dengan cara yang bermanfaat baik bagi bisnis sendiri maupun untuk pembangunan.

Definisi mengenai CSR di Indonesia disebut juga sebagai Tanggung Jawab Sosial dan Lingkungan (TJSL). Pelaksanaan CSR sudah mulai dijalankan di Indonesia setelah disahkannya Undang-Undang No.40 Tahun 2007 Pasal 74 tentang Perseroan Terbatas bahwa CSR yang dikenal dalam Undang-Undang ini sebagaimana yang termuat dalam Pasal 1 Ayat (3) yang berbunyi :

Tanggung Jawab Sosial dan Lingkungan adalah komitmen Perseroan untuk berperan serta dalam pembangunan ekonomi berkelanjutan guna meningkatkan kualitas hidup dan lingkungan yang bermanfaat, baik bagi Perseroan sendiri, komunitas setempat, maupun pada masyarakat pada umumnya.

Definisi lain mengenai CSR disampaikan oleh Johnson and Johnson dalam buku Nor Hadi (2011:46) yang mengatakan bahwa "corporate Social Responsibility (CSR) is about how companies manage the business processes to produce an overall positive impact on society". Definisi tersebut berarti bagaimana cara mengelola perusahaan baik sebagian maupun secara keseluruhan memiliki dampak positif bagi dirinya dan lingkungan. Untuk itu, perusahaan harus mampu mengelola bisnis operasinya dengan menghasilkan produk yang berorientasi secara positif terhadap masyarakat dan lingkungan.

Apabila perusahaan telah melakukan bentuk tanggung jawab sosialnya terhadap lingkungan maka perusahaan tersebut telah berkontribusi terhadap pembangunan ekonomi dan peningkatan kualitas hidup dan lingkungan. Bila perusahaan tidak melakukan tanggung jawab sosialnya terhadap lingkungan maka kemungkinan besar perusahaan tersebut akan menghadapi berbagai tuntutan dari masyarakat luas.

Konsep CSR pada umumnya menyatakan bahwa tanggung jawab perusahaan tidak hanya terhadap pemiliknya atau pemegang saham saja tetapi juga terhadap para stakeholder yang terkait dan/ atau terkena dampak dari keberadaan perusahaan. Perusahaan yang menjalankan aktivitas CSR akan memperhatikan dampak operasional perusahaan terhadap kondisi sosial dan lingkungan dan berupaya agar dampaknya positif. Sehingga dengan adanya konsep CSR diharapkan kerusakan lingkungan yang terjadi di dunia, mulai dari penggundulan hutan, polusi udara dan air, hingga perubahan iklim dapat dikurangi (Fahrizqi, 2010).

"Dari pelaksanaan maupun pengungkapan CSR, perusahaan memang tidak akan mendapat profit atau keuntungan, yang diharapkan dari kegiatan ini adalah benefit berupa citra perusahaan" (Untung, 2008: 32-33).

Pengungkapan terhadap CSR di Indonesia pun telah diatur dalam PSAK No.1 Revisi 2009 paragraf 12 yang menyebutkan bahwa :

Entitas dapat pula menyajikan, terpisah dari laporan keuangan, laporan mengenai lingkungan hidup dan laporan nilai tambah (value added statement), khususnya bagi industri dimana faktor lingkungan hidup memegang peranan penting dan bagi industri yang menganggap karyawan sebagai kelompok pengguna laporan yang memegang peranan penting.

\section{Indikator Pengungkapan CSR}

Menilai pengungkapan CSR di Indonesia dapat menggunakan standar yang dikembangkan dari Global Reporting Initiative (GRI). Standar GRI dipilih karena telah 
diterima oleh umum dalam melaporkan kinerja ekonomi, lingkungan dan sosial dari suatu organisasi. Selain itu, standar GRI juga telah disetujui oleh berbagai pemangku kepentingan (www.globalreporting.org).

Standar GRI yang akan digunakan terdiri dari tiga fokus pengungkapan, yaitu indikator kinerja ekonomi (economic performance indicator), indikator kinerja lingkungan (environment performance indicator), dan indikator kinerja sosial (social performance indicator) yang dibagi menjadi tiga di antaranya adalah tenaga kerja, hak asasi manusia, masyarakat dan sosial, serta tanggung jawab produk (www.globalreporting.org).

Dengan pedoman GRI inilah pengungkapan informasi CSR pada laporan tahunan perusahaan dapat diukur melalui metode content analysis, yaitu pemberian skor yang mencantumkan angka "1" pada setiap item GRI yang diungkapkan dan memberikan angka "0" pada setiap item GRI yang tidak diungkapkan. Kemudian jumlahkan semua angka 1, maka didapatkan jumlah angka yang merupakan total informasi pengungkapan CSR yang dilaporkan pada laporan tahunan (www.ncsr-id.org).

\section{Faktor-Faktor yang Mempengaruhi Pengungkapan CSR Profitabilitas}

Profitabilitas menurut Brigham \& Houston (2011) adalah "hasil akhir bersih dari berbagai kebijakan dan keputusan yang dilakukan oleh perusahaan”.

Profitabilitas diartikan juga sebagai kemampuan manajemen untuk memperoleh laba. "Laba terdiri dari laba kotor, laba operasi dan laba bersih. Untuk memperoleh laba di atas rata-rata, manajemen harus mampu meningkatkan pendapatan (revenue) dan mengurangi semua beban (expenses) atas pendapatan" (Prawironegoro, 2006).

Profitabilitas dapat dikatakan sebagai gambaran atas kinerja operasi perusahaan. Baik buruknya kinerja perusahaan dapat dilihat dari tingkat profitabilitasnya. "Sehingga semakin tinggi tingkat profitabilitas perusahaan maka semakin besar pengungkapan informasi sosial yang dilakukannya" (Anggraini, 2006). Dengan kepeduliannya terhadap masyarakat (sosial) menghendaki manajemen untuk membuat perusahaan menjadi profitable (Belkaoui dan Karpik dalam Anggraini, 2006).

\section{Jenis-Jenis Rasio Profitabilitas}

Menurut Kasmir (2010) mengenai rasio profitabilitas menyatakan bahwa :

Rasio profitabilitas merupakan rasio untuk menilai kemampuan perusahaan dalam mencari keuntungan. Rasio ini juga memberikan ukuran tingkat efektivitas manajemen suatu perusahaan.

Kemudian, Fahmi Irham (2014:81) mengatakan bahwa "semakin baik rasio profitabilitas, maka semakin baik menggambarkan kemampuan tingginya perolehan keuntungan perusahaan."

Rasio profitabilitas (profitability ratio) terdiri atas tiga jenis yaitu seperti berikut (Van Horne dan Wachowicz, 2005) :

a. Gross Profit Margin (Margin Laba Kotor), merupakan rasio yang menghitung sejauh mana kemampuan perusahaan dalam menghasilkan laba.

$\mathrm{GPM}=\underline{\text { Penjualan bersih }- \text { Harga pokok penjualan }}$

$$
\text { Penjualan bersih }
$$


b. Return On Asset (ROA), merupakan rasio yang menunjukkan kemampuan manajemen perusahaan dalam menghasilkan income dari pengelolaan aktiva yang dimiliki untuk menghasilkan laba.

$\mathrm{ROA}=\underline{\text { Laba bersih setelah pajak }}$

Total aktiva

c. Return On Equity (ROE), menunjukkan kemampuan manajemen perusahaan dalam mengelola ekuitas yang dimiliki perusahaan untuk mendapatkan net income yang tersedia bagi pemegang saham.

$$
\mathrm{ROE}=\frac{\text { Laba bersih setelah pajak }}{\text { Ekuitas pemegang saham }}
$$

\section{Leverage}

Utang perusahaan bertujuan untuk mendongkrak kinerja keuangan perusahaan. Jika perusahaan hanya mengandalkan modal atau ekuitas saja, hal tersebut akan mempersulit perusahaan dalam melebarkan bisnisnya karena dibutuhkan adanya modal tambahan. Dengan demikian peran utang adalah untuk membantu mengatasi hal tersebut.

Utang yang dimiliki perusahaan berkaitan dengan leverage, yang merupakan kemampuan perusahaan dalam memenuhi pembayaran semua kewajibannya, baik kewajiban jangka pendek maupun kewajiban jangka panjang (Wijayanti, 2013).

"Perusahaan dengan tingkat leverage yang tinggi berarti sangat bergantung pada pinjaman dari luar. Sedangkan perusahaan dengan tingkat leverage yang rendah lebih banyak dibiayai dengan modal sendiri" (Purnasiwi, 2011). Dengan demikian perusahaan akan melakukan pengungkapan informasi yang lebih luas, salah satunya informasi mengenai tanggung jawab sosial perusahaan. Pengungkapan informasi yang lebih luas digunakan untuk memberitahukan kepada kreditor atas kontribusi perusahaan dalam pelakasanaan CSR yang dilakukan.

\section{Jenis-Jenis Rasio Leverage}

Rasio leverage menghubungkan keputusan pendanaan yang dilakukan oleh perusahaan, dimana perusahaan lebih memilih didanai oleh utang atau dengan modal sendiri. Adapun jenis-jenis rasio leverage dapat diukur dengan cara sebagai berikut (Kasmir, 2010:112) :

a. Debt to Assets Ratio (Debt Ratio), merupakan rasio utang yang digunakan untuk mengukur seberapa besar aktiva perusahaan membiayai utang atau seberapa besar utang perusahaan mempengaruhi pengelolaan aktiva.

$$
\text { Rasio Utang }=\frac{\text { Total Utang }}{\text { Total Aktiva }}
$$

b. Debt to Equity Ratio, merupakan rasio yang digunakan untuk menilai utang dengan ekuitas. Rasio ini berguna untuk mengetahui jumlah dana yang disediakan peminjam (kreditor) dengan pemilik perusahaan.

$$
\text { DER }=\frac{\text { Total Utang }}{\text { Total Ekuitas }}
$$

\section{Ukuran Perusahaan}

Ukuran perusahaan adalah skala yang menentukan besar atau kecilnya perusahaan. Ukuran suatu perusahaan telah diatur dalam Keputusan Ketua Bapepam Nomor Kep- 
11/PM/1997 Tentang Perubahan Peraturan Nomor IX.C.7, yang mendefinisikan bahwa ukuran suatu perusahaan dapat dilihat berdasarkan jumlah kekayaan yang dimiliki (total aset) yang tidak lebih dari Rp100.000.000.000,00 (seratus miliar rupiah) untuk perusahaan menengah atau kecil yang didirikan di Indonesia.

Adapun definisi dari total aset (total aktiva) menurut Kurniawati (2013) adalah "segala sumber daya yang dikuasai oleh perusahaan sebagai akibat dari transaksi masa lalu dan diharapkan akan memberikan manfaat ekonomi bagi perusahaan di masa yang akan datang."

Suatu perusahaan agar mendapatkan legitimasi dari masyarakat hendaknya melakukan aktivitas sosial lebih banyak untuk keberlanjutan usahanya. Dalam teori legitimasi menyatakan bahwa perusahaan dapat bertahan apabila masyarakat di sekitar perusahaan merasa bahwa perusahaan telah melakukan aktivitas bisnisnya sesuai dengan sistem nilai yang dimiliki masyarakat (Rahajeng, 2010). Dengan demikian perusahaan akan mengungkapkan informasi sosial lebih banyak. Karena perusahaan akan mendapat lebih banyak perhatian dari para stakeholder.

\section{Pengukuran Ukuran Perusahaan}

Cara yang digunakan untuk menentukan ukuran (size) sebuah perusahaan yaitu dengan melakukan transformasi terhadap total aktiva perusahaan ke dalam bentuk logaritma (Darwis, 2009). Cara tersebut digunakan untuk menyederhanakan nilai total aktiva milik perusahaan yang bernilai milyaran rupiah. Maka, apabila dinyatakan kedalam rumus akan terlihat seperti berikut :

$$
\text { Size }=\log (\text { Total Aktiva })
$$

\section{Pengaruh Profitabilitas Terhadap Pengungkapan Corporate Social Responsibility}

Semakin tinggi tingkat profitabilitas maka semakin luas pengungkapan informasi sosial yang dilakukan oleh perusahaan. Adapun luas pengungkapan yang dilakukan oleh perusahaan adalah untuk mendapatkan dukungan dan simpati dari para stakeholdernya. Perusahaan dengan kinerja yang tinggi akan meningkatkan nilai perusahaan dalam proses pembentukan image yang sangat berpengaruh untuk mendapatkan kepercayaan dari para stakeholder (Widianto, 2011).

Dilakukannya pengungkapan tanggung jawab sosial secara luas ketika perusahaan memiliki tingkat laba yang tinggi juga digunakan untuk memperoleh image yang baik dan meningkatkan reputasi perusahaan di mata investor dan masyarakat. Hal tersebut sesuai dengan teori stakeholder, dimana perusahaan berdiri bukan hanya untuk kepentingannya sendiri tetapi juga harus memperhatikan pihak yang mempengaruhi maupun yang dipengaruhinya.

Berdasarkan pernyataan tersebut, maka hipotesis yang didapat adalah :

Ho1 : Profitabilitas tidak berpengaruh terhadap pengungkapan corporate social responsibility.

Ha1 : Profitabilitas berpengaruh terhadap pengungkapan corporate social responsibility. 


\section{Pengaruh Leverage Terhadap Pengungkapan Corporate Social Responsibility}

Perusahaan dengan tingkat leverage yang tinggi akan melakukan penambahan informasi yang diperlukan untuk memberitahukan kepada para kreditor atas kinerja perusahaan dalam berkontribusi terhadap aturan pemerintah, yaitu melaksanakan tanggung jawab sosial perusahaan.

Tingkat leverage perusahaan yang tinggi juga akan mendorong perusahaan dalam melakukan pengungkapan tanggung jawab sosialnya. Sesuai dengan teori agensi bahwa perusahaan akan mengeluarkan biaya-biaya untuk kepentingan manajemen, salah satunya yang dapat meningkatkan reputasi perusahaan di mata masyarakat yaitu biaya-biaya yang terkait dengan tanggung jawab sosial perusahaan (Nursiam dan Gemitasari, 2013).

Atas uraian tersebut, hipotesis yang didapat adalah :

Ho2 : Leverage tidak berpengaruh terhadap pengungkapan corporate social responsibility.

Ha2 : Leverage berpengaruh terhadap pengungkapan corporate social responsibility.

\section{Pengaruh Ukuran Perusahaan Terhadap Pengungkapan Corporate Social Responsibility}

Besar kecilnya suatu perusahaan dapat diukur dari keseluruhan aktiva yang dimiliki oleh perusahaan tersebut. Keseluruhan aktiva yang dimiliki perusahaan dapat digunakan untuk menggambarkan seberapa besar kemampuan perusahaan dalam mendanai kegiatan operasionalnya. Perusahaan yang besar cenderung memiliki aktivitas yang lebih banyak dan kompleks, maka pelaksanaan CSR yang dilakukan oleh perusahaan dapat digunakan untuk menghindari resiko yang akan ditanggung di masa depan.

Kegiatan bisnis yang dilakukan perusahaan dapat menimbulkan dampak sosial dan lingkungan, sehingga praktik pengungkapan sosial dan lingkungan dapat digunakan perusahaan untuk menghindari konflik sosial dan lingkungan (Chairi dalam Kristi, 2012). Dengan demikian, hal tersebut dapat digunakan untuk meningkatkan reputasi dan image perusahaan di mata masyarakat.

Dari uraian tersebut maka hipotesis yang dapat ditarik adalah :

Ho3 : Ukuran perusahaan tidak berpengaruh terhadap pengungkapan corporate social responsibility.

Ha3 : Ukuran Perusahaan berpengaruh terhadap pengungkapan corporate social responsibility.

\section{Populasi dan Sampel}

\section{METODE PENELITIAN}

Populasi dalam penelitian ini adalah perusahaan pertambangan yang terdaftar pada Bursa Efek Indonesia periode 2013-2015. 
Penentuan sampel dalam penelitian ini dengan menggunakan metode purposive sampling. Kriteria sampel yang digunakan dalam penelitian ini adalah :

a. Perusahaan sektor pertambangan yang terdaftar di Bursa Efek Indonesia yang mempublikasikan laporan keuangan lengkap pada periode tahun 2013 sampai dengan tahun 2015.

b. Perusahaan sektor pertambangan yang laporan keuangan tahunannya tidak mengalami kerugian pada periode tahun 2013 sampai dengan tahun 2015.

\section{Metode Pengumpulan Data}

Metode pengumpulan data yang digunakan dalam penelitian ini adalah :

1. Metode Penelitian Lapangan (Field Research)

2. Metode Penelitian Kepustakaan (Library Research) Jenis Data

\section{Variabel Penelitian}

\section{Variabel Dependen (Y)}

Pada penelitian ini yang menjadi variabel dependen adalah Pengungkapan Corporate Social Responsibility.

Untuk menilai pengungkapan CSR dapat menggunakan Corporate Social Responsibility Disclosure Index (CSRDI) berdasarkan standar dari GRI (Global Reporting Initiatives). Penilaian CSRDI pada penelitian ini sesuai dengan penelitian Haniffa et al. (2005) dalam Sayekti dan Wondabio (2007). Pendekatan untuk menghitung CSRDI pada dasarnya menggunakan pendekatan metode content analysis, yaitu setiap item GRI yang diungkapkan diberi nilai 1 dan nilai 0 pada setiap item GRI yang tidak diungkapkan. Adapun rumus perhitungan CSRDI adalah sebagai berikut (Haniffa et al. dalam Sayekti dan Wondabio, 2007) :

Keterangan:

$$
\operatorname{CSRDIj}=\underset{\mathrm{Nj}}{\sum \mathrm{Xij}^{\mathrm{Nj}}}
$$

CSRDIj : Corporate Social Responsibility Disclosure Index perusahaan j

$\sum X i j \quad$ : Jumlah item GRI yang diungkapkan. Jika diungkapkan diberi nilai 1 dan jika tidak diungkapkan diberi nilai 0. Maka, akan didapat $0 \leq \mathrm{CSRDIj} \leq 1$

$\mathrm{Nj} \quad$ : Jumlah item GRI yang seharusnya diungkapkan untuk perusahaan $\mathrm{j}$ (91 tem pengungkapan)

\section{Variabel Independen $(\mathrm{X})$}

Variabel independen dalam penelitian ini adalah profitabilitas, leverage dan ukuran perusahaan.

Profitabilitas $\left(\mathrm{X}_{1}\right)=\mathrm{ROA}($ Return On Asset $)$

Leverage $\left(\mathrm{X}_{2}\right) \quad=$ Rasio Utang $=$ Total Utang

Total Aktiva

Ukuran Perusahaan $\left(\mathrm{X}_{3}\right)=\quad$ Size $=\log ($ Total Aktiva $)$ 


\section{Desain Penelitian}

Desain penelitian yang digunakan dalam penelitian ini adalah jenis penelitian kausal, yaitu penelitian untuk mengetahui pengaruh antara satu atau lebih variabel bebas (independent variable) terhadap variabel terikat (dependent variable).

\section{Hipotesis}

Ho1 : Profitabilitas tidak berpengaruh terhadap pengungkapan corporate social responsibility.

Ha1 : Profitabilitas berpengaruh terhadap pengungkapan corporate social responsibility.

Ho2 : Leverage tidak berpengaruh terhadap pengungkapan corporate social responsibility.

Ha2 : Leverage berpengaruh terhadap pengungkapan corporate social responsibility.

Ho3 : Ukuran perusahaan tidak berpengaruh terhadap pengungkapan corporate social responsibility.

Ha3 : Ukuran Perusahaan berpengaruh terhadap pengungkapan corporate social responsibility.

\section{Model Kerangka Berpikir}

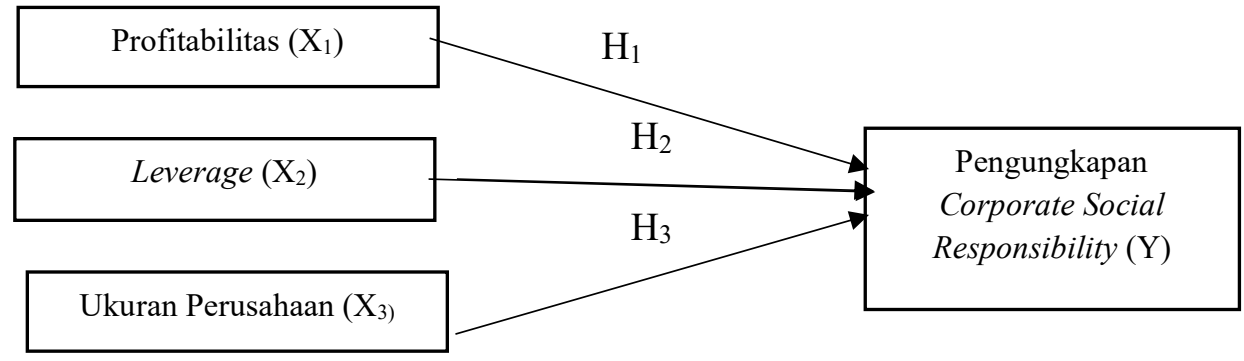

\section{Metode Analisis Data}

Metode analisis data yang digunakan dalam penelitian ini adalah analisis deskriptif dan analisis statistik:

\section{Analisis Deskriptif}

Analisis deskriptif ini bertujuan untuk memberikan penjelasan mengenai variable yang digunakan dalam penelitian yang meliputi dependen $(\mathrm{Y})$ dan variable independen $(\mathrm{X}) \mathrm{Uji}$ Asumsi Klasik

\section{Analisis Statistik}

Kebenaran hipotesis yang diajukan perlu dibuktikan dengan menggunakan uji regresi linier berganda. Beberapa tahapan yang dilakukan sebelum melakukan uji regresi linier berganda diperlukan uji asumsi klasik terlebih dahulu. 


\section{Uji Asumsi Klasik}

\section{Uji Normalitas}

Data dapat dikatakan normal bila data atau titik titik tersebar disekitar garis diagonal dan penyebarannya mengikuti garis diagonalnya. Metode yang lebih akurat untuk menguji normalitas adalah dengan uji Kolmogorov Smirnov, yaitu dengan melihat angka nilai signifikansinya lebih dari 0.05 .

\section{Uji Multikolonieritas}

Model regresi yang baik seharusnya tidak terjadi korelasi diantara variabel bebas. Untuk mendeteksi ada atau tidaknya gejala multikolinieritas dalam suatu model regresi dapat diketahui dengan kriteria Variance Inflation Factor (VIF) sebagai berikut:

1. Jika angka tolerance di bawah 0,10 dan VIF $\geq 10$, dikatakan terdapat gejala multikolineritas.

2. Jika angka tolerance di atas 0,10 dan VIF $\leq 10$, dikatakan tidak terdapat gejala multikolineritas.

\section{Uji Autokorelasi}

Pengujian ada tidaknya autokorelasi dalam persamaan ini digunakan uji Durbin Watson (DW - test). Model regresi yang baik adalah model yang tidak mengandung autokorelasi. Nilai uji statistik Durbin-Watson harus menunjukkan nilai 1-2 atau tidak boleh lebih dari tiga.

\section{Uji Heteroskedastisitas}

Ada beberapa cara untuk mendeteksi ada atau tidaknya heteroskedastisitas yaitu :

1. Melihat Grafik Plot

2. Uji Glejser

\section{Menilai Goodnes of Fit Suatu Model}

\section{Koefisien Determinasi $\left(\mathbf{R}^{2}\right)$}

Menurut Ghozali (2016:95) "koefisien determinasi $\left(R^{2)}\right.$ pada intinya mengukur seberapa jauh variabel independen dapat menjelaskan variabel dependen”. Nilai $\mathrm{R}^{2}$ adalah 0 dan $1\left(0<\mathrm{R}^{2}<1\right)$, dimana suatu regresi yang baik akan menghasilkan nilai $\mathrm{R}^{2}$ yang tinggi. Hal ini berarti bahwa keseluruhan variabel bebas secara bersama-sama mampu menerangkan variabel terkaitnya. Sedangkan nilai $\mathrm{R}^{2}$ yang kecil berarti kemampuan variabel-variabel dependen sangat terbatas.

\section{Uji Regresi Linier Berganda}

Metode analisis regresi linear berganda merupakan suatu bentuk hubungan linear antara dua atau lebih variabel independen dengan variabel dependennya. Uji yang dilakukan dalam menganalisis penelitian ini adalah sebagai berikut:

\section{Uji F}

Uji ini merupakan pengujian untuk melihat pengaruh dari variabel-variabel independen secara simultan terhadap variabel dependen. Dalam pengujian ini sebelumnya dirumuskan hipotesisnya.

H0: Variabel-Variabel Independen secara simultan tidak berpengaruh terhadap variabel dependen

H1: Variabel- variabel Independen secara simultan berpengaruh terhadap variabel dependen Kriteria pengujian untuk uji $\mathrm{F}$ berdasarkan signifikansi sebagai berikut : 
Jika Signifikansi $>0,05$ maka $\mathrm{H} 0$ diterima

Jika Signifikansi $<0,05$ maka H0 ditolak

\section{Uji t}

Pengujian penelitian ini sebelumnya dirumuskan hipotesisnya.

H0: Variabel Independen tidak berpengaruh terhadap variabel dependen

H1: Variabel Independen berpengaruh terhadap variabel dependen

Kriteria pengujian untuk uji t berdasarkan signifikansi sebagai berikut:

Jika Signifikansi $>0,05$ maka $\mathrm{H} 0$ diterima

Jika Signifikansi $<0,05$ maka H0 ditolak

\section{Persamaan Regresi Linier Berganda}

Model persamaan regresi berganda dalam penelitian ini adalah sebagai berikut:

\begin{tabular}{ll}
\hline $\mathbf{Y}=\mathbf{a}+\mathbf{\beta}_{\mathbf{1}} \mathbf{X}_{\mathbf{1}}+\mathbf{\beta}_{\mathbf{2}} \mathbf{X}_{\mathbf{2}}+\mathbf{\beta}_{\mathbf{3}} \mathbf{X}_{\mathbf{3}}+\mathbf{e}$ \\
\hline Keterangan: & \\
$\mathrm{Y}$ & $=$ Pengungkapan Corporate Social Responsibility \\
$\mathrm{X}_{1}$ & $=$ Profitabilitas \\
$\mathrm{X}_{2}$ & $=$ Leverage \\
$\mathrm{X}_{3}$ & $=$ Ukuran Perusahaan \\
$\beta_{1} \beta_{2} \beta_{3}$ & $=$ Koefisien Regresi \\
$\mathrm{a}$ & $=$ Konstanta \\
$\mathrm{e}$ & $=$ Error Term
\end{tabular}

\section{Analisis Deskriptif}

\section{ANALISIS HASIL DAN PEMBAHASAN}

Analisis deskriptif dilakukan untuk memberikan gambaran dan deskripsi dari daytyadata dalam penelitian ini. Analisis deskripsi dapat dilihat dalam tabel 1 berikut ini.

Tabel

Statistik Deskripsi

Descriptive Statistics

\begin{tabular}{|c|c|c|c|c|c|}
\hline & $\mathrm{N}$ & $\begin{array}{l}\text { Minimu } \\
\mathrm{m}\end{array}$ & \begin{tabular}{|l} 
Maximu \\
$\mathrm{m}$
\end{tabular} & Mean & $\begin{array}{l}\text { Std. } \\
\text { Deviation }\end{array}$ \\
\hline PROFITABILI & 44 & ,0109 &, 1820 &, 079507 &, 0522046 \\
\hline LEVERAGE & 44 &, 1782 &, 6571 &, 386198 &, 1282835 \\
\hline SIZE & 44 & 11,1959 & 13,4994 & $\begin{array}{l}12,6549 \\
30\end{array}$ &, 5428162 \\
\hline CSRD & 44 & , 1099 &, 4505 & ,274970 &, 0844677 \\
\hline $\begin{array}{l}\text { Valid } \\
\text { (listwise) }\end{array}$ & 44 & & & & \\
\hline
\end{tabular}

\section{Uji Asumsi Klasik}

Uji Normalitas

Uji normalitas yang digunakan dalam penelitian juga menggunakan uji Kolmogrov Smirnov. Data dikatakan berdistribusi normal jika nilai signifikansi yang diperoleh lebih besar dari nilai signifikansi yang ditetapkan sebelumnya yaitu 5\% 


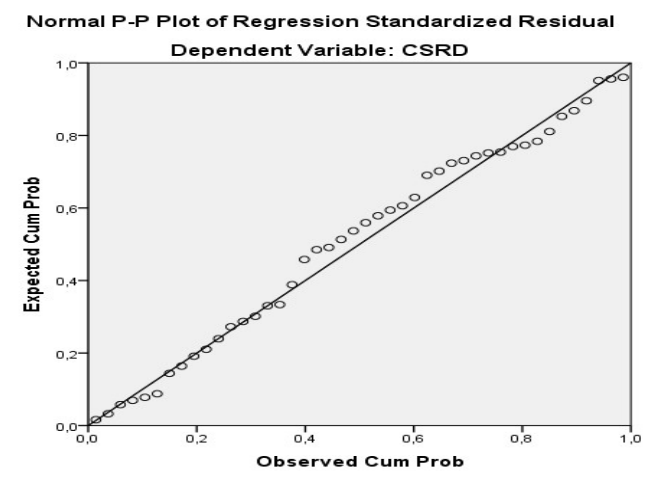

\section{Gambar \\ Hasil Uji Normalitas Menggunakan Grafik P-Plot}

Selain dengan melihat grafik, uji normalitas data dalam penelitian ini juga dilihat dengan menggunakan uji statistik Kolmogorov-Smirnov. Jika nilai signifikansi dari pengujian Kolmogorov-Smirnov Test lebih dari 0,05 berarti data yang digunakan dalam penelitian adalah data normal.

\section{Tabel}

\section{Uji Statistik Kolmogorov-Smirnov}

\section{Tests of Normality}

\begin{tabular}{|l|l|l|l|}
\hline \multirow{2}{*}{} & \multicolumn{3}{|l|}{ Kolmogorov-Smirnov $^{\mathrm{a}}$} \\
\cline { 2 - 4 } & Statistic & Df & Sig. \\
\hline PROFITABILITAS &, 126 & 44 &, 079 \\
LEVERAGE &, 103 & 44 &, $200^{*}$ \\
SIZE &, 102 & 44 &, $200^{*}$ \\
CSRD &, 078 & 44 &, $200^{*}$ \\
\hline
\end{tabular}

Terlihat bahwa semua variabel berdistribusi normal. Hal ini dapat dilihat dari nilai signifikansi masing-masing variabel yang memiliki nilai lebih besar dari 0,05.

\section{Uji Multikolonieritas}

Uji multikolonieritas bertujuan untuk menguji apakah dalam model regresi ditemukan adanya korelasi antar variabel independen, yaitu dengan melihat Tolerance dan Variance Inflation Factor (VIF).

$$
\text { Tabel }
$$

Hasil Uji Multikolonieritas

\begin{tabular}{|ll|l|l|}
\hline \multirow{2}{*}{ Model } & \multicolumn{2}{|l|}{ Collinearity Statistics } \\
\cline { 2 - 3 } & Tolerance & VIF \\
\hline 1 & (Constant) & & \\
& PROFITABILITAS &, 986 & 1,014 \\
& LEVERAGE &, 959 & 1,043 \\
SIZE &, 946 & 1,057 \\
\hline
\end{tabular}

a. Dependent Variable: CSRD

Berdasarkan Tabel di atas, dapat dilihat bahwa nilai Tolerance lebih dari 0,1 dan nilai Variance Inflation Factor (VIF) di bawah angka 10 untuk setiap variabel. Nilai tolerance 
untuk profitabilitas, leverage dan size masing-masing sebesar 0,986; 0,959; dan 0,946. Serta masing-masing variabel mempunyai nilai VIF sebesar 1,$014 ; 1,043$; dan 1,057. Dengan demikian dapat disimpulkan bahwa model persamaan regresi tidak terjadi korelasi antar variabel.

\section{Uji Autokorelasi}

Nilai uji statistik Durbin-Watson harus menunjukkan nilai 1-2 atau tidak boleh lebih dari tiga .

Model Summary

\section{Hasil Uji Autokorelasi Durbin Watson}

\begin{tabular}{|l|l|l|l|l|l|}
\hline Model & $\mathrm{R}$ & R Square & $\begin{array}{l}\text { Adjusted } \\
\text { Square }\end{array}$ & $\begin{array}{l}\text { Std. Error of the } \\
\text { Estimate }\end{array}$ & Durbin-Watson \\
\hline 1 &, $422^{\mathrm{a}}$ &, 178 &, 117 &, 0793806 & 1,648 \\
\hline
\end{tabular}

a. Predictors: (Constant), SIZE, PROFITABILITAS, LEVERAGE

b. Dependent Variable: CSRD

Diperoleh nilai D-W sebesar 1,648. Menurut kriteria Singgih Santoso (2010) yang menyatakan bahwa jika nilai DW diantara -2 sampai 2 berarti tidak terjadi autokorelasi. Maka dapat disimpulkan bahwa dalam penelitian ini tidak terdapat autokorelasi.

\section{Uji Heteroskedastisitas}

Berikut grafik yang menunjukkan bahwa model regresi pada penelitian ini bebas dari gangguan heterokedastisitas.

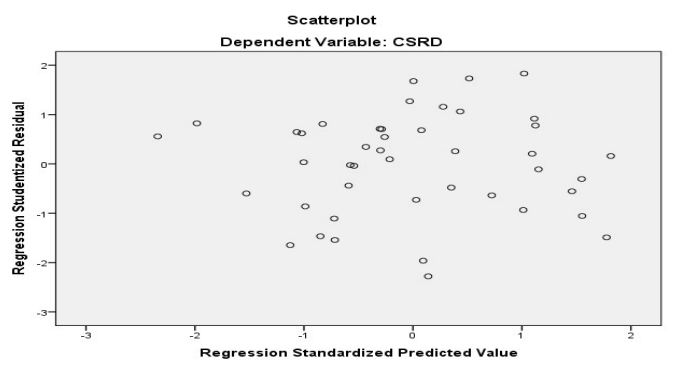

\section{Gambar : Hasil Uji Heteroskedastisitas}

Grafik scatterplot menunjukkan bahwa data tersebar di atas dan di bawah angka 0 (nol) pada sumbu Y dan tidak terdapat suatu pola yang jelas pada penyebaran data tersebut. Hal ini berarti tidak terjadi Heteroskedastisitas pada model persamaan regresi, sehingga model regresi layak digunakan untuk memprediksi Pengungkapan Corporate Social Responsibility berdasarkan variabel yang mempengaruhinya, yaitu Profitabilitas, Leverage dan Ukuran Perusahaan.

\section{Koefisien Determinasi $\left(\mathbf{R}^{2}\right)$}

Koefisien determinasi $\left(R^{2}\right)$ pada intinya mengukur seberapa jauh kemampuan model dalam menerangkan variasi variabel dependen. 
Tabel

Hasil Uji Koefisien Determinasi $\left(R^{2}\right)$

Model Summary ${ }^{\mathrm{b}}$

\begin{tabular}{|l|l|l|l|}
\hline Model & $\mathrm{R}$ & $\mathrm{R}$ Square & Adjusted R Square \\
\hline 1 &, $422^{\mathrm{a}}$ &, 178 &, 117 \\
\hline
\end{tabular}

a. Predictors: (Constant), SIZE, PROFITABILITAS, LEVERAGE

b. Dependent Variable: CSRD

Nilai Adjusted $\mathrm{R}^{2}$ sebesar 0,117 atau 11,7\%. Hal ini dapat diartikan bahwa Pengungkapan Corporate Social Responsibility dapat dijelaskan oleh variabel Profitabilitas, Leverage dan Size sebesar 11,7\%, sedangkan sisanya 0,883 atau 88,3\% (1-0,117) dijelaskan oleh faktor-faktor lain yang tidak digunakan dalam penelitian ini.

\section{Uji Regresi Linier Berganda}

Uji Simultan (Uji F)

Uji statistik F digunakan untuk menguji ada tidaknya pengaruh secara bersama-sama (simultan) variabel-variabel independen secara signifikan terhadap variabel dependen. Pengujian dilakukan dengan tingkat signifikansi 0,05 atau $a=5 \%$.

Tabel

Hasil Uji Statistik F

ANOVA

\begin{tabular}{|ll|l|l|l|l|l|}
\hline \multicolumn{2}{|l|}{ Model } & $\begin{array}{l}\text { Sum of } \\
\text { Squares }\end{array}$ & Df & $\begin{array}{l}\text { Mean } \\
\text { Square }\end{array}$ & F & Sig. \\
\hline 1 & $\begin{array}{l}\text { Regressio } \\
\mathrm{n}\end{array}$ &, 055 & 4 &, 018 & 2,896 &, $047^{\mathrm{b}}$ \\
$\begin{array}{l}\text { Residual } \\
\text { Total }\end{array}$ &, 252 & 40 &, 006 & & \\
&, 307 & 44 & & & \\
\hline
\end{tabular}

a. Dependent Variable: CSRD

b. Predictors: (Constant), SIZE, PROFITABILITAS, LEVERAGE

Nilai $F_{\text {hitung }}$ sebesar 2,896 dengan signifikansi 0,047. Nilai signifikansi lebih kecil dari 0,05 maka model regresi dapat disimpulkan bahwa Profitabilitas, Leverage dan Ukuran Perusahaan secara serentak (simultan) berpengaruh atau merupakan penjelas yang signifikan terhadap variabel dependen Pengungkapan Corporate Social Responsibility.

\section{Uji Parsial (Uji t)}

Uji statistik t pada dasarnya menunjukkan seberapa jauh pengaruh satu variabel penjelas/independen secara individual dalam menerangkan variabel dependen serta untuk membuktikan variabel mana yang paling dominan. Pengujian dilakukan dengan tingkat signifikansi 0,05 atau $\mathrm{a}=5 \%$. 
Tabel

Hasil Uji Statistik $t$

\begin{tabular}{|c|c|c|c|c|c|c|}
\hline \multicolumn{7}{|c|}{ Coefficients $^{\mathrm{a}}$} \\
\hline \multirow{2}{*}{\multicolumn{2}{|c|}{ Model }} & \multicolumn{2}{|c|}{$\begin{array}{l}\text { Unstandardized } \\
\text { Coefficients }\end{array}$} & $\begin{array}{l}\text { Standardiz } \\
\text { ed } \\
\text { Coefficien } \\
\text { ts }\end{array}$ & \multirow[b]{2}{*}{$\mathrm{t}$} & \multirow[b]{2}{*}{ Sig. } \\
\hline & & B & Std. Error & Beta & & \\
\hline \multirow[t]{4}{*}{1} & (Constant) &,- 559 & ,288 & & $-1,941$ & ,059 \\
\hline & $\begin{array}{l}\text { PROFITABIL } \\
\text { ITAS }\end{array}$ & &, 234 &, 077 &, 536 &, 595 \\
\hline & LEVERAGE &,- 073 &, 096 &,- 111 &,- 760 & ,452 \\
\hline & SIZE &, 067 &, 023 & ,433 & 2,937 &, 005 \\
\hline
\end{tabular}

a. Dependent Variable: CSRD

Hasil uji statistik adalah sebagai berikut :

a. Pengaruh Profitabilitas Terhadap Pengungkapan Corporate Social Responsibility

Pengujian variabel Profitabilitas menunjukkan bahwa nilai koefisiensi sebesar 0,125 dengan nilai signifikansi sebesar 0,595 > 0,05, yang artinya "Profitabilitas tidak berpengaruh terhadap Pengungkapan Corporate Social Responsibility”.

\section{b. Pengaruh Leverage Terhadap Pengungkapan Corporate Social Responsibility}

Pengujian variabel Leverage menunjukkan bahwa nilai koefisiensi sebesar -0,073 dengan nilai signifikansi sebesar 0,452 >0,05, yang artinya "Leverage tidak berpengaruh terhadap Pengungkapan Corporate Social Responsibility”.

c. Pengaruh Ukuran Perusahaan Terhadap Pengungkapan Corporate Social Responsibility

Pengujian variabel Ukuran Perusahaan menunjukkan bahwa nilai koefisiensi sebesar 0,067 dengan nilai signifikansi sebesar $0,005<0,05$, yang artinya bahwa variabel "Ukuran Perusahaan berpengaruh terhadap Pengungkapan Corporate Social Responsibility".

\section{Persamaan Regresi Linier Berganda}

Berdasarkan hasil pada tabel 6 , maka persamaan regresi yang dihasilkan adalah sebagai berikut :

Keterangan :

Y = Pengungkapan Corporate Social Responsibility

a $\quad=$ Konstanta

$\beta_{1} X_{1}=$ Koefisien Regresi Profitabilitas

$\beta_{2} \mathrm{X}_{2}=$ Koefisien Regresi Leverage

$\beta_{3} X_{3}=$ Koefisien Regresi Ukuran Perusahaan

$\mathrm{e} \quad=$ Error Term

Berdasarkan persamaan regresi tersebut, maka dapat dianalisis pengaruh dari masingmasing variabel independen terhadap Pengungkapan Corporate Social Responsibility sebagai berikut :

a. Konstanta sebesar -0,559 artinya jika Profitabilitas $\left(\mathrm{X}_{1}\right)$, Leverage $\left(\mathrm{X}_{2}\right)$ dan Size $\left(\mathrm{X}_{3}\right)=$ 0, maka Pengungkapan Corporate Social Responsibility (Y) nilainya adalah -0,559.

b. Koefisien regresi Profitabilitas $\left(\mathrm{X}_{1}\right)$ sebesar 0,125. Hal ini menunjukkan bahwa setiap kenaikan 1 persen dari Profitabilitas akan menyebabkan kenaikan Pengungkapan 
Corporate Social Responsibility yang diterima sebesar nilai koefisiennya, yaitu $0,125 \%$.

c. Koefisien regresi Leverage $\left(\mathrm{X}_{2}\right)$ sebesar $-0,073$. Hal ini menunjukkan bahwa setiap kenaikan 1 persen dari Leverage akan menyebabkan penurunan Pengungkapan Corporate Social Responsibility yang diterima sebesar nilai koefisiennya, yaitu $0,073 \%$.

d. Koefisien regresi Size $\left(\mathrm{X}_{3}\right)$ sebesar 0,067. Hal ini menunjukkan bahwa setiap kenaikan 1 persen dari Size akan menyebabkan kenaikan Pengungkapan Corporate Social Responsibility yang diterima sebesar nilai koefisiennya, yaitu $0,067 \%$.

\section{Pembahasan dan Interprestasi}

Hubungan dengan Landasan Teori dan Peneliti Terdahulu

\section{Pengaruh Profitabilitas Terhadap Pengungkapan Corporate Social Responsibility}

Variabel profitabilitas mempunyai tingkat signifikansi sebesar 0,595. Hal ini berarti menolak $\mathrm{H}_{\mathrm{a} 1}$ sehingga dapat dikatakan bahwa profitabilitas tidak berpengaruh terhadap pengungkapan corporate social responsibility karena tingkat signifikansi yang dihasilkan lebih besar dari 0,05 .

Hal ini menjelaskan bahwa semakin tinggi tingkat profitabilitas perusahaan maka semakin kecil pengungkapan informasi sosial yang dilakukannya. Dengan demikian ketika perusahaan memperoleh laba yang tinggi belum tentu perusahaan tersebut banyak melakukan kegiatan sosial karena kemungkinan besar perusahaan tersebut hanya berfokus terhadap perolehan laba yang diterimanya. Sehingga dapat disimpulkan bahwa perusahaan tidak berusaha mencari dukungan stakeholder, melainkan hanya mencari keuntungan semata.

Selanjutnya dikatakan bahwa pengungkapan sosial perusahaan justru memberikan kerugian kompetitif (competitive disadvantage) karena perusahaan harus mengeluarkan tambahan biaya untuk mengungkapkan informasi sosial tersebut (Anggraini, 2006). Dengan demikian apabila perusahaan tetap memperluas informasi CSR, hal ini akan berpengaruh terhadap tingkat perolehan laba yang diterima perusahaan.

Hasil penelitian ini sejalan dengan penelitian yang dilakukan oleh Dewi dan Priyadi (2013) yang menggunakan variabel yang sama tetapi dengan objek penelitian yang berbeda, yaitu terhadap perusahaan manufaktur yang terdaftar di Bursa Efek Indonesia pada periode tahun 2009-2011.

Namun hasil penelitian ini bertolak belakang dengan hasil penelitian yang dilakukan oleh Fahrizqi (2010) yang menunjukkan bahwa Profitabilitas berpengaruh terhadap Pengungkapan Corporate Social Responsibility dengan menggunakan objek penelitian pada perusahaan manufaktur yang terdaftar di Bursa Efek Indonesia pada periode tahun 20052008 .

\section{Pengaruh Leverage Terhadap Pengungkapan Corporate Social Responsibility}

Variabel leverage mempunyai tingkat signifikansi sebesar 0,452. Hal ini berarti menolak $\mathrm{H}_{\mathrm{a} 2}$ sehingga dapat dikatakan bahwa leverage tidak berpengaruh terhadap pengungkapan corporate social responsibility karena tingkat signifikansi yang dihasilkan lebih besar dari 0,05 .

Hal ini menjelaskan bahwa jika dikaitkan dengan teori agensi, manajemen perusahaan akan mengurangi pengungkapan tanggung jawab sosial yang dibuatnya agar tidak menjadi sorotan dari para debtholders (Belkaoui dan Karpik dalam Sembiring, 2005). Sehingga dapat disimpulkan bahwa perusahaan lebih memprioritaskan pihak kreditor dibandingkan dengan 
melaksanakan CSR, dikarenakan adanya kewajiban perusahaan dalam memenuhi hak-hak yang harus diterima oleh pihak kreditor.

Dengan demikian apabila semakin tinggi leverage, kemungkinan besar perusahaan akan mengalami pelanggaran terhadap kontrak utang, maka manajer akan berusaha untuk melaporkan laba sekarang lebih tinggi dibandingkan laba di masa depan. Sehingga perusahaan akan mengurangi biaya-biaya yang mempengaruhi tingkat perolehan laba (Belkaoui dan Karpik dalam Anggraini, 2006). Dengan kata lain, perusahaan mencari image yang baik di mata kreditor dengan mengurangi biaya pelaksanaan CSR yang dilakukan oleh perusahaan.

Hasil penelitian ini sejalan dengan penelitian yang dilakukan oleh Fahrizqi (2010) yang menggunakan variabel yang sama tetapi dengan objek penelitian yang berbeda, yaitu pada perusahaan manufaktur yang terdaftar di Bursa Efek Indonesia pada periode tahun 2005-2008.

Akan tetapi, hasil penelitian ini memiliki perbedaan hasil dengan penelitian yang dilakukan oleh Purnasiwi (2011) yang menyatakan bahwa tidak adanya pengaruh antara Leverage terhadap Pengungkapan Corporate Social Responsibility dengan menggunakan variabel yang sama namun dengan objek penelitian yang berbeda, yaitu pada perusahaanperusahaan yang terdaftar di Bursa Efek Indonesia pada tahun 2009.

\section{Pengaruh Ukuran Perusahaan Terhadap Pengungkapan Corporate Social Responsibility}

Variabel ukuran perusahaan mempunyai tingkat signifikansi sebesar 0,005. Hal ini berarti menerima $\mathrm{H}_{\mathrm{a} 3}$ sehingga dapat dikatakan bahwa ukuran perusahaan berpengaruh terhadap pengungkapan corporate social responsibility karena tingkat signifikansi yang dihasilkan lebih kecil dari 0,05 .

Hal ini menjelaskan bahwa keseluruhan aktiva yang dimiliki perusahaan dapat digunakan untuk mengukur kemampuan perusahaan dalam mendanai kegiatan operasionalnya. Selain itu, aktiva perusahaan merupakan gambaran harta yang dimiliki oleh perusahaan yang dapat digunakan untuk mendanai pelaksanaan CSR yang dilakukan oleh perusahaan sebagai cara untuk menghindari resiko yang akan ditanggung di masa depan.

Kegiatan bisnis yang dilakukan perusahaan dapat menimbulkan dampak sosial dan lingkungan, sehingga praktik pengungkapan sosial dan lingkungan dapat digunakan perusahaan untuk menghindari konflik sosial dan lingkungan (Chairi dalam Kristi, 2012). Dengan demikian, hal tersebut dapat digunakan untuk meningkatkan reputasi dan image perusahaan di mata masyarakat.

Hasil penelitian ini sejalan dengan penelitian yang dilakukan oleh Yuliawati dan Sukirman (2015) yang menggunakan variabel yang sama tetapi dengan objek penelitian yang berbeda, yaitu terhadap perusahaan manufaktur yang terdaftar di Bursa Efek Indonesia pada tahun 2013.

Namun hasil penelitian ini tidak sesuai dengan hasil penelitian yang dilakukan oleh Nugroho (2016) yang menyatakan bahwa Ukuran Perusahaan tidak berpengaruh terhadap Pengungkapan Corporate Social Responsibility yang menggunakan objek penelitian pada perusahaan manufaktur di BEI tahun 2010-2014.

\section{KESIMPULAN}

Berdasarkan hasil penelitian dari pembahasan yang dilakukan, maka kesimpulan yang dapat diambil adalah sebagai berikut :

1. Profitabilitas tidak berpengaruh terhadap Pengungkapan Corporate Social
Responsibility. 
2. Leverage tidak berpengaruh terhadap Pengungkapan Corporate Social Responsibility.

3. Ukuran perusahaan berpengaruh terhadap Pengungkapan Corporate Social Responsibility.

\section{SARAN}

Berdasarkan hasil analisis pembahasan serta kesimpulan pada penelitian ini, adapun saran-saran yang dapat diberikan agar mendapat hasil yang lebih baik yaitu :

1. Bagi peneliti selanjutnya, diharapkan dapat menggunakan variabel-variabel lain di luar dari variabel yang digunakan dalam penelitian ini untuk memperoleh hasil lebih baik yang dapat menggambarkan faktor-faktor lainnya yang mempengaruhi Pengungkapan Corporate Social Responsibility dan disarankan untuk menambahkan jumlah sampel serta periode pengamatan penelitian yang lebih panjang, sehingga hasil yang diperoleh akan lebih menjelaskan gambaran kondisi yang sesungguhnya.

2. Bagi pihak perusahaan, diharapkan mampu menunjukkan kinerja yang lebih baik dan lebih banyak mengungkapkan informasi kepada investor mengenai perkembangan perusahaan, serta kontribusi perusahaan dalam pembangunan ekonomi berkelanjutan agar dapat menarik perhatian para investor.

\section{DAFTAR PUSTAKA}

Anggara, Sahya. 2015. Metode Penelitian Administrasi, Bandung: CV. Pustaka Setia.

Anggraini, F. R. R. 2006. Pengungkapan Informasi Sosial dan Faktor-Faktor yang Mempengaruhi Pengungkapan Informasi Sosial dalam Laporan Keuangan Tahunan (Studi Empiris pada Perusahaan-Perusahaan yang Terdaftar di Bursa Efek Indonesia). Simposium Nasional Akuntansi IX, Padang.

Aprilia, Icha. 2016. Pengaruh Leverage, Profitabilitas dan Kepemilikan Saham Publik terhadap Corporate Social Responsibility (Studi Empiris pada Perusahaan Sektor Pertambangan yang Terdaftar di Bursa Efek Indonesia (BEI) tahun 2012-2014). Skripsi. Fakultas Ekonomi dan Bisnis, Universitas Mercu Buana, Jakarta.

Darwis, Herman. 2009. Ukuran Perusahaan, Profitabilitas, dan Financial Leverage terhadap Pengungkapan Tanggung Jawab Sosial Perusahaan High Profile di BEI. Jurnal Keuangan dan Perbankan Vol.13 No.1 Januari 2009. Fakultas Ekonomi, Universitas Khairun Ternate.

Data Laporan Tahunan Perusahaan 2013-2015. www.idx.co.id yang diakses pada tanggal 12 April 2017.

Dewi, Sukmawati Safitri dan Maswar Patuh Priyadi. 2013. Pengaruh Karakteristik Perusahaan terhadap Corporate Social Responsibility Disclosure pada Perusahaan Manufaktur yang terdaftar di BEI. Jurnal Ilmu \& Riset Akuntansi Vol.2 No.3. Sekolah Tinggi Ilmu Ekonomi Indonesia, Surabaya.

Fahrizqi, Anggara. 2010. Faktor-Faktor yang Mempengaruhi Pengungkapan Corporate Social Responsibility (CSR) dalam Laporan Tahunan Perusahaan (Studi Empiris pada Perusahaan Manufaktur yang Terdaftar dalam Bursa Efek Indonesia). Skripsi. Fakultas Ekonomi, Universitas Diponegoro, Semarang.

Ghozali, Imam. 2016. Aplikasi Analisis Multivariate dengan Program SPSS. Semarang: Badan Penerbit Universitas Diponegoro.

Global Reporting Initiative. $\underline{w w w . g l o b a l r e p o r t i n g . o r g}$ yang diakses pada tanggal 11 April 2017.

Greenpeace International. www.greenpeace.org yang diakses pada tanggal 12 April 2017.

Hadi, Nor. 2011. Corporate Social Responsibility. Yogyakarta: Graha Ilmu. 
Karina, Lovink Angel Dwi. 2013. Analisis Faktor-Faktor yang Mempengaruhi Pengungkapan CSR (Studi Empiris pada Perusahaan Manufaktur yang Terdaftar di Bursa Efek Indonesia tahun 2011). Fakultas Ekonomika dan Bisnis, Universitas Diponegoro, Semarang.

Kasmir. 2010. Pengantar Manajemen Keuangan. Jakarta: Prenadamedia Group.

Kristi, Agatha Aprinda. 2012. Faktor-Faktor yang Mempengaruhi Pengungkapan Corporate Social Responsibility pada Perusahaan Publik di Indonesia. Jurusan Akuntansi, Fakultas Ekonomi dan Bisnis, Universitas Brawijaya.

Kurniawan, Benny. 2012. Metodologi Penelitian. Tangerang: Jelajah Nusa.

National Center for Sustainability Reporting. www.ncsr-id.org yang diakses pada tanggal 27 April 2017.

Nugroho, Ismoyo Adi. 2016. Pengaruh Karakteristik Perusahaan dan Corporate Governance terhadap Pengungkapan Corporate Social Responsibility pada Perusahaan Manufaktur di BEI tahun 2010-2014. Publikasi Ilmiah. Fakultas Ekonomi dan Bisnis, Universitas Muhammadiyah Surakarta.

Nur, Marzully dan Denies Priantinah. 2012. Analisis Faktor-Faktor yang Mempengaruhi Pengungkapan Corporate Social Responsibility di Indonesia (Studi Empiris pada Perusahaan Berkategori High Profile yang Listing di Bursa Efek Indonesia). Jurnal Nominal Volume I Nomor I Tahun 2012. Fakultas Ekonomi, Universitas Negeri Yogyakarta.

Nurkhin, Ahmad. 2009. Corporate Governance dan Profitabilitas; Pengaruhnya terhadap Pengungkapan Tanggung Jawab Sosial Perusahaan (Studi Empiris pada Perusahaan yang Tercatat di Bursa Efek Indonesia). Tesis. Program Studi Magister Akuntansi, Program Pascasarjana, Universitas Diponegoro, Semarang.

Nursiam dan Rina Gemitasari. 2013. Analisis Faktor-Faktor yang Mempengaruhi Pengungkapan Tanggung Jawab Sosial Perusahaan (Studi Empiris pada Perusahaan Manufaktur yang Terdaftar di Bursa Efek Indonesia Tahun 2009-2011). Universitas Muhammadiyah Surakarta.

Peraturan Pemerintah No.47 Tahun 2012 Tentang Tanggung Jawab Sosial dan Lingkungan Perseroan Terbatas

Prawironegoro, Darsono. 2006. Manajemen Keuangan. Jakarta: Diadit Media.

Prihadi, Toto. 2012. Analisis Laporan Keuangan Teori dan Aplikasi. Jakarta: PPM.

Purnasiwi, Jayanti. 2011. Analisis Pengaruh Size, Profitabilitas dan Leverage terhadap Pengungkapan CSR pada Perusahaan yang Terdaftar di Bursa Efek Indonesia. Skripsi. Fakultas Ekonomi, Universitas Diponegoro, Semarang.

Sayekti, Yosefa dan Ludovicus Sensi Wondabio. 2007. Pengaruh CSR Disclosure terhadap Earning Response Coefficient (Suatu Studi Empiris Pada Perusahaan yang Terdaftar Di Bursa Efek Jakarta). Simposium Nasional Akuntansi X. Unhas Makassar.

Sembiring, Eddy Rismanda. 2005. Pengaruh Karakteristik Perusahaan terhadap Pengungkapan Tanggung Jawab Sosial: Studi Empiris pada Perusahaan yang Tercatat (Go-Public) di Bursa Efek Jakarta. Tesis. Program Studi Magister Sains Akuntansi, Program Pascasarjana, Universitas Diponegoro, Semarang.

Undang-Undang Nomor 40 Tahun 2007 Tentang Perseroan Terbatas.

Untung, Hendrik Budi. 2008. Corporate Social Responsibility. Jakarta: Sinar Grafika.

Widianto, Hari Suryono. 2011. Pengaruh Profitabilitas, Likuiditas, Leverage, Aktivitas, Ukuran Perusahaan dan Corporate Governance terhadap Praktik Pengungkapan Sustainability Report (Studi pada Perusahaan-Perusahaan yang Listed (Go-Public) di Bursa Efek Indonesia (BEI) Periode 2007-2009). Skripsi. Fakultas Ekonomi, Universitas Diponegoro, Semarang. 